\title{
STRATEGI PEMBERDAYAAN MASYARAKAT MELALUI PROGRAM KETERAMPILAN PRODUKTIF DI PKBM RAWASARI, JAKARTA TIMUR
}

\section{Puji Hadiyanti}

\begin{abstract}
Community participation is very important to achieve the objectives of any training or learning process. This qualitative research was conducted in the Center for Teavhing and Learning Activities (PKBM) in Rawasari, Jakarta, aiming at discovering the strategy applied in the Center. Based on the data collected and analysed, this research finds out notable progress achieved, but the the Center has not implemented wholistic strategy. Beside identifying some problems, this research provides a set of recommendation related to improving the exisiting strategy to empower the community through productive competence.
\end{abstract}

Keywords: Strategy, empowering, community, productive competence.

\section{PENDAHULUAN}

\section{Latar Belakang Masalah}

Kegiatan membangun masyarakat terkait erat dengan memberdayakan masyarakat. Memberdayakan masyarakat bertujuan memerangi kemiskinan, kesenjangan, dan mendorong masyarakat menjadi lebih aktif serta penuh inisiatif. Pemberdayaan masyarakat sendiri merupakan upaya untuk memandirikan masyarakat melalui perwujudan potensi kemampuan yang mereka miliki. Salah satu pengembangan potensi manusia dapat diwujudkan melalui kegiatan pendidikan berbasis kemasyarakatan. Kegiatan ini menekankan pentingnya memahami kebutuhan masyarakat dan cara pemecahan permasalahan oleh masyarakat dengan memperhatikan potensi yang ada di lingkungannya.

Pendidikan yang bertumpu pada masyarakat adalah pendidikan yang diselenggarakan masyarakat, berada di tengah masyarakat, mengandalkan kekuatan masyarakat, menjawab kebutuhan masyarakat, dan pengelolaan pendidikan ada di tangan masyarakat. Pendidikan yang bertumpu pada masyarakat mengarah pada pemandirian masyarakat dalam mengelola pendidikannya. Semua badan, instansi atau organisasi dapat mengambil bagian di dalam pendidikan yang bertumpu pada masyarakat karena tujuannya adalah untuk memberdayakan masyarakat secara keseluruhan, tidak mengadakan pembedaan, serta mereka juga tidak mengendalikan jalannya pendidikan karena pendidikan ini adalah milik masyarakat. Dengan demikian, orientasinya adalah kebutuhan sekarang. Namun, tidak menutup kemungkinan untuk menyiapkan masyarakat melanjutkan pendidikan ke jenjang yang lebih tinggi. Sebagai contohnya adalah Pusat Kegiatan Belajar Masyarakat (PKBM). Kegiatan yang diselenggarakan oleh PKBM adalah Kejar Paket A, Kejar Paket B, dan Kejar Paket $C$ yang tujuannya adalah untuk menjembatani kebutuhan masyarakat yang tidak mampu bersekolah di jalur sekolah.

PKBM itu sendiri merupakan salah satu strategi perwujudan yang telah, sedang, dan akan terus dirintis dan dibumikan untuk menggali serta menumbuhkembangkan pendidikan berbasis kemasyarakatan yang merupakan konsep dan aspek acuan kerja Pendidikan Luar Sekolah (PLS). Selain kegiatan Kejar Paket, PKBM juga melaksanakan program pemberdayaan dalam bentuk keterampilan produktif yang berorientasi pada kebutuhan sekarang, di antaranya adalah kursus yang diperuntukkan bagi kaum ibu, remaja putri, dan pemuda, seperti kursus menjahit, sablon, montir, dan memasak. Semuanya itu bertujuan untuk meningkatkan keterampilan dan produktivitas masyarakat sehingga mereka menjadi mandiri yang pada akhirnya meningkatkan taraf hidup masyarakat.

Berdasarkan pemaparan di atas maka perlu dikembangkan sebuah strategi pemberdayaan masyarakat yang nantinya akan membantu mereka lebih berdaya. Hal ini dikarenakan selama ini belum ditemukan hasil atau perubahan nyata sebagai dampak apakah program ini cukup efektif untuk memberdayakan masyarakat. Keberhasilan program tentu tidak terlepas dari strategi yang diterapkan dalam proses pelaksanaan program. Untuk mengetahui hal ini, diperlukan pengkajian untuk menggambarkan proses tersebut. Dari penggambaran proses pelaksanaan program dapat diketahui apakah 
program tersebut telah sesuai dengan strategi pemberdayaan masyarakat.

\section{Masalah Penelitian}

Strategi yang diterapkan oleh PKBM Rawasari dalam pemberdayaan masyarakat melalui program keterampilan produktif merupakan permasalahan pokok dalam penelitian ini. Adapun secara rinci, permasalahannya dapat dirumuskan sebagai berikut. 1. Apakah program-program yang ada di PKBM Rawasari wujud dari pemberdayaan?

2. Sejauh mana program-program yang ada di PKBM Rawasari dapat memberdayakan masyarakat?

3. Bagaimana program-program yang ada di PKBM Rawasari dapat terealisasi sehingga mencapai tujuan?

4. Upaya-upaya apa saja yang dilakukan oleh PKBM Rawasari dalam memberdayakan masyarakat?

\section{KAJIAN TEORETIS}

\section{Konsep Strategi Pemberdayaan Masyarakat}

Strategi adalah cara untuk mengerahkan tenaga, dana, daya, dan peralatan yang dimiliki guna mencapai tujuan yang ditetapkan. Arti pemberdayaan masyarakat itu sendiri adalah suatu proses yang mengembangkan dan memperkuat kemampuan masyarakat untuk terus terlibat dalam proses pembangunan yang berlangsung secara dinamis sehingga masyarakat dapat menyelesaikan masalah yang dihadapi serta dapat mengambil keputusan secara bebas (independent) dan mandiri (Sumaryo, 1991). Hikmat (2001:12) menjelaskan ada beberapa faktor internal yang menghambat pemberdayaan antara lain, kurang bisa untuk saling mempercayai, kurang daya inovasi atau kreativitas, mudah pasrah atau menyerah atau putus asa, aspirasi dan cita-cita rendah, tidak mampu menunda menikmati hasil kerja, wawasan waktu yang sempit, familisme, sangat tergantung pada bantuan pemerintah, sangat terikat pada tempat kediamannya dan tidak mampu atau tidak bersedia menempatkan diri sebagai orang lain.

Bagaimana memberdayakan masyarakat merupakan suatu masalah tersendiri yang berkaitan dengan hakikat dari power atau daya (mengandung pengertian "kemampuan", "kekuatan" ataupun "kekuasaan") serta hubungan antarindividu atau lapisan sosial yang lain. Pada dasarnya setiap individu dilahirkan dengan daya. Hanya saja kadar daya itu berbeda antara satu individu dengan individu yang lain. Kondisi ini dipengaruhi oleh berbagai faktor yang saling terkait (interlinking factors), seperti pengetahuan, kemampuan, status, harta, kedudukan, dan jenis kelamin. Faktor-faktor yang saling terkait tersebut pada akhirnya membuat hubungan antarindividu, dengan dikotomi subjek (penguasa) dan objek yang dikuasai meliputi kaya-miskin, laki-lakiperempuan, guru-murid, pemerintah-warganya, serta antaragen pembangunan dan si miskin. Bentuk relasi sosial yang dicirikan dengan dikotomi subjek dan objek tersebut merupakan relasi yang ingin "diperbaiki" melalui proses pemberdayaan.

Pemberdayaan merupakan proses pematahan atau breakdown dari hubungan atau relasi antara subjek dengan objek. Proses ini mementingkan adanya "pengakuan" subjek akan "kemampuan" atau "daya" (power) yang dimiliki objek. Secara garis besar, proses ini melihat pentingnya mengalir daya (flow of power) dari subjek ke objek dengan memberi kesempatan untuk meningkatkan hidupnya dengan memakai sumber yang ada. Pada akhirnya, "pengakuan" oleh subjek terhadap kemampuan individu miskin untuk dapat mewujudkan harapannya merupakan bukti bahwa individu tersebut mempunyai daya. Mengalirnya daya ini dapat berwujud suatu upaya dari objek untuk meningkatkan hidupnya dengan memakai daya yang ada padanya serta dibantu juga dengan daya yang dimiliki subjek.

Dalam pengertian yang lebih luas, mengalirnya daya ini merupakan upaya atau cita-cita untuk mengintegrasikan masyarakat miskin ke dalam aspek kehidupan yang lebih luas. Hasil akhir dari proses pemberdayaan adalah beralihnya fungsi individu yang semula objek menjadi subjek (yang baru) sehingga relasi sosial yang ada nantinya hanya dicirikan dengan relasi antarsubjek dengan subjek yang lain. Dengan kata lain, proses pemberdayaan mengubah pola relasi lama subjek-objek menjadi subjek-subjek. Hal ini merupakan prasyarat krusial dalam mewujudkan makna pemberdayaan masyara-kat secara utuh. Hubungan yang timpang atau yang menghalalkan bentuk hubungan yang subordinat atau asimetris cenderung mengabadikan penindasan dan kemiskinan. Peralihan fungsi objek menjadi subjek baru merupakan tantangan dalam segala macam implementasi kebijakan. Masih banyak ditemukan kebijakan dengan dalih pemberdayaan dan membantu yang miskin tetapi masih menempatkan objek pada posisinya semula. Artinya, ia tetap sebagai pihak yang "dikontrol dan dikuasai" oleh subjek.

Seringkali, mengalirnya daya untuk mengalihfungsikan individu miskin yang semula objek menjadi subjek ini tidak dapat terwujud dengan baik. Kondisi tersebut dapat memunculkan countervailing power dari objek yang dipakai untuk "menantang" konfigurasi 
daya (power) yang sudah mapan. Objek biasanya akan dibantu oleh pihak luar yang berkepentingan sama, misalnya Lembaga Swadaya Masyarakat (LSM). Proses tersebut juga berkaitan dengan penciptaan aset, yaitu menciptakan suatu dasar ekonomi minimum untuk kelompok yang selama ini tersingkir. Asumsinya dengan peningkatan taraf hidup melalui penciptaan aset tersebut, lapisan miskin akan memiliki means to intervene yang lebih kuat di dalam proses pembangunan.

Untuk merangsang lahirnya gerakan masyarakat yang bermula pada komunitas lokal, ada sejumlah syarat yang terlebih dahulu harus dipenuhi. Tiga syarat terpenting adalah sebagai berikut.

1. Restrukturisasi kelembagaan komunitas. Tatanan dasar yang mengatur kehidupan komunitas perlu direorientasi dari pola feodalistis dan kolonial (pemerintahan yang kuat dan paternalistik) ke pola pemerintahan yang lebih profesional dan masyarakat yang dinamis. Tatanan baru perlu menjamin kebebasan masyarakat berekspresi dan mengembangkan inisiatif lokal untuk memenuhi kebutuhan-kebutuhan asasinya. Masyarakat harus menjadi subjek dan penentu utama dari segala kegiatan pembangunan dalam arti yang sesungguhnya.

2. Meninjau kembali segala kebijakan yang memperlemah kebudayaan masyarakat dan menggantinya dengan kebijakan yang lebih memihak pada upaya peningkatan keberdayaan masyarakat desa untuk memperbaiki nasib sendiri.

3. Pada aras program, pendekatan top-down harus segera diganti pendekatan bottom up, tercermin dari mekanisme pengambilan keputusan dan penyelenggaraan program. Istilah program pengembangan masyarakat seharusnya tidak lagi berkonotasi program masuk desa melainkan program dari desa. Artinya, dalam segala kegiatan pembangunan desa masyarakat desa itulah yang menjadi subjek dan pelaku utama. Mulai dari penjajakan masalah dan kebutuhan, perencanaan, pelaksanaan, pegawasan, evaluasi, sampai pemanfaatan hasil-hasilnya. Dalam keadaan demikian, masyarakat akan menerima kegagalan maupun keberhasilan program secara bertanggung jawab.

Dengan demikian, dapat dikatakan bahwa strategi pemberdayaan masyarakat adalah cara untuk mengaktualisasikan potensi yang sudah dimiliki oleh masyarakat. Oleh karena itu, pendekatan pemberdaya-an masyarakat adalah penekanan pentingnya masyarakat lokal yang mandiri sebagai suatu sistem yang mengorganisir diri mereka sendiri.
Pendekatan pemberdayaan yang demikian tentunya diharapkan memberikan peranan kepada individu bukan sebagai objek, tetapi sebagai pelaku (aktor) yang menentukan hidup mereka dengan mengupayakan berbagai potensi yang dimilikinya.

Proses pemberdayaan masyarakat bertitik tolak untuk memandirikan masyarakat agar dapat meningkatkan taraf hidupnya sendiri dengan menggunakan dan mengakses sumber daya setempat sebaik mungkin. Sasaran utama pemberdayaan masyarakat adalah masyarakat miskin. Dalam prosesnya perlu diperhatikan bahwa perempuan akan terlibat secara aktif. Proses pemberdayaan masyarakat didampingi oleh suatu tim fasilitator yang bersifat multidisiplin. Tim pemberdayaan masyarakat sebaiknya terdiri dari laki-laki dan perempuan. Peran utama tim pemberdayaan masyarakat adalah mendampingi masyarakat dalam melaksanakan proses pemberdayaan. Peran tim pemberdayaan masyarakat pada awal proses sangat aktif tetapi akan berkurang selama proses berjalan sampai masyarakat sudah mampu melanjutkan kegiatannya secara mandiri. Pemberdayaan masyarakat dilaksanakan melalui beberapa tahapan sebagai berikut.

1. Tahap pertama seleksi lokasi

Seleksi wilayah dilakukan sesuai dengan kriteria yang disepakati oleh lembaga, pihak-pihak terkait, dan masyarakat. Penetapan kriteria ini penting agar tujuan lembaga dalam pemberdayaan masyarakat akan tercapai serta pemilihan lokasi dilakukan dengan sangat baik.

2. Tahap kedua sosialisasi pemberdayaan masyarakat Sosialisasi pemberdayaan masyarakat adalah suatu kegiatan yang sangat penting untuk menciptakan komunikasi serta dialog dengan masyarakat. Sosialisasi pemberdayaan masyarakat pada masyarakat membantu untuk meningkatkan pengertian pada masyarakat dan pihak terkait tentang program. Proses sosialisasi sangat menentukan ketertarikan masyarakat untuk berperan dan terlibat di dalam program.

3. Tahap ketiga proses pemberdayaan masyarakat

Tahap ini terdiri dari kegiatan:

a. kajian keadaan pedesaan partisipatif,

b. pengembangan kelompok,

c. penyusunan rencana dan pelaksanaan kegiatan, serta

d. monitoring dan evaluasi partisipatif.

Maksud pemberdayaan masyarakat adalah meningkatkan kemampuan dan kemandirian masyarakat dalam meningkatkan taraf hidupnya (tujuan umum). Dalam proses tersebut masyarakat bersama-sama: 
a. mengidentifikasi dan mengkaji permasalahan, potensinya serta peluangnya;

b. menyusun rencana kegiatan kelompok berdasarkan hasil kajian;

c. menerapkan rencana kegiatan kelompok; dan

d. memantau proses dan hasil kegiatannya secara terus menerus [Monitoring dan Evaluasi Partisipatif (M\&EP)]

Dalam semua kegiatan, sering dimanfaatkan teknik dan alat visualisasi yang mendukung diskusi antara masyarakat dan memudahkan proses pemberdayaan. Diharapkan bahwa melalui teknikteknik tersebut, proses kajian, penyusunan rencana kegiatan, penerapan, monitoring, dan evaluasi dilakukan secara sistematis. Teknik-teknik kajian sering disebut Participatory Rural Appraisal (PRA). Monitoring dan evaluasi merupakan suatu tahap yang sangat penting dan bermaksud untuk memperbaiki proses secara terus menerus agar tujuan dapat tercapai. Aspek-aspek yang dimonitor dan dievaluasi meliputi proses, pencapaian, dan dampak proses pemberdayaan.

\section{Tahap keempat pemandirian masyarakat}

Proses pemberdayaan masyarakat merupakan suatu proses pembelajaran terus menerus bagi masyarakat dengan tujuan kemandirian masyarakat dalam upaya-upaya peningkatan taraf hidupnya. Artinya, bahwa peran tim pemberdayaan masyarakat akan pelan-pelan dikurangi dan akhirnya berhenti. Peran tim pemberdayaan kelompok sebagai fasilitator akan dipenuhi oleh pengurus kelompok atau pihak lain yang dianggap mampu oleh masyarakat. Waktu yang diperlukan untuk pelaksanaan pemberdayaan masyarakat tidak tentu. Pemberdayaan masyarakat adalah suatu proses yang akan berjalan terus menerus. Seringkali kegiatan memerlukan waktu dan tidak dapat dilakukan secara terburu-buru.

\section{Konsep PKBM}

PKBM adalah wadah dari berbagai kegiatan pembelajaran masyarakat yang diharapkan pada pemberdayaan potensi untuk menggerakkan pembangunan di bidang sosial, ekonomi, dan budaya. PKBM merupakan tempat belajar yang dibentuk dari, oleh, dan untuk masyarakat dalam rangka usaha meningkatkan pengetahuan, keterampilan, sikap, hobi, dan bakat warga masyarakat yang bertitik tolak dari kebermaknaan dan kebermanfaatan potensi sumber daya manusia dan sumber daya alam yang ada di lingkungannya (Sihombing, 2000). Pelembagaan PKBM dilaksanakan dengan memanfaatkan gedunggedung SD, balai desa, puskesmas yang karena berbagai hal tidak dimanfaatkan lagi, seperti adanya gedung baru dan gedung milik pribadi yang rela diberikan untuk digunakan menjadi PKBM. Pembentukan PKBM dilakukan dengan memperhatikan sumber-sumber potensi yang terdapat pada daerah yang bersangkutan, terutama jumlah kelompok sasaran dan jenis usaha atau keterampilan yang secara ekonomi, sosial, dan budaya dapat dikembangkan untuk meningkatkan kesejahteraan warga belajar khususnya dan warga masyarakat sekitarnya pada umumnya.

Program yang digulirkan tidak terbatas pada program dari instansi PLS, tetapi juga program dari instansi lain yang oleh masyarakat dirasakan manfaatnya, seperti perkebunan, perindustrian, pertanian, perdagangan, kesehatan, keluarga berencana, dan olahraga. Seluruh program belajar yang ada di PKBM selalu terkait dengan mata pencaharian. Hal ini seperti yang tertuang dalam visi dan misi PKBM, yaitu mewujudkan PKBM sebagai tempat belajar utama dan pertama bagi masyarakat untuk mencerdaskan kehidupannya melalui jalur PLS. Adapun misi PKBM adalah memberikan pelayanan pendidikan dan mendidik warga masyarakat untuk memenuhi segala jenis pendidikannya melalui PLS.

PKBM memiliki fungsi utama dan pendukung. Fungsi utama PKBM adalah sebagai wadah berbagai kegiatan belajar masyarakat untuk meningkatkan pengetahuan, keterampilan, dan sikap yang diperlukan untuk mengembangkan diri dan masyarakat. Fungsi pendukung PKBM adalah sebagai pusat informasi bagi masyarakat sekitar dan pemerintah, pusat jaringan informasi dan kerja sama bagi lembaga di luar masyarakat, sebagai tempat koordinasi, konsultasi, komunikasi, dan sebagai tempat kegiatan penyebarluasan program dan teknologi tepat guna.

\section{Konsep Pelaksanaan Program Keterampilan Produktif di PKBM}

Program keterampilan produktif merupakan salah satu kegiatan pemberdayaan masyarakat yang bertumpu pada pendidikan berbasis masyarakat. Dalam melaksanakan kegiatan pendidikan yang berbasis masyarakat, terdapat empat unsur di dalamnya. Unsur-unsur tersebut adalah sebagai berikut.

1. Mementingkan warga belajar. Di sini ada beberapa penekanan, seperti pentingnya mendengar suara warga belajar, mengggunakan apa yang dikatakan warga belajar sebagai dasar untuk mengembangkan program belajar, dan mempercayai bahwa setiap orang punya kemampuan belajar karena setiap warga belajar memiliki kekuatan, keterampilan, pengetahuan, serta pengalaman 
2. Kesetaraan di antara warga belajar dan pembina program. Unsur ini mendorong warga belajar agar ikut aktif terlibat dalam kegiatan belajar dan kegiatan kemasyarakatan. Perhatikan kebutuhan belajar masyarakat karena mereka sebenarnya tahu apa yang mereka butuhkan.

3. Program dimulai dari perspektif yang kritis. Menggunakan pendekatan yang kritis menekankan pentingnya perbaikan kemampuan dasar masyarakat, meningkatkan kemampuan yang sudah ada, dan partisipasi dalam setiap kegiatan.

4. Pembangunan masyarakat. Unsur ini menekankan bahwa program belajar harus berlokasi di masyarakat, menjawab kebutuhan belajar masyarakat, menciptakan rasa memiliki, dirancang, diputuskan, dan diatur oleh masyarakat sehingga mereka merupakan bagian dari yang lebih besar.

Unsur-unsur tersebut akan dapat dicapai dengan menempuh hal-hal berikut.

1. Kegiatan belajar dilakukan dalam kelompok kecil atas dasar kesamaan minat.

2. Tutor atau narasumber secara berangsur-angsur harus dapat menyerahkan tanggung jawab kegiatan belajar kepada peserta.

3. Sedapat mungkin, kepemimpinan diserahkan kepada peserta atau warga belajar.

4. Pendamping berperan sebagai fasilitator.

5. Semua keputusan harus dibuat secara mufakat di antara peserta atau warga belajar.

6. Kegiatan belajar senantiasa berdasarkan pengalaman-pengalaman dan masalah-masalah yang dihadapi oleh peserta.

7. Metode dan teknik yang digunakan sesuai dengan kondisi warga belajar.

8. Bahan belajar diarahkan pada kebutuhan atau kenyataan hidup sehari-hari peserta.

Schwartz dalam Suharto (2006) mengemukakan lima tugas yang dapat dilaksanakan oleh penyelenggara program pemberdayaan masyarakat sebagai berikut.

1. Mencari persamaan mendasar antara persepsi masyarakat mengenai kebutuhan mereka sendiri dan aspek-aspek tuntutan sosial yang dihadapi mereka.

2. Mendeteksi dan menghadapi kesulitan-kesulitan yang menghambat banyak orang dan membuat frustasi usaha-usaha orang untuk mengidentifikasi kepentingan mereka dan kepentingan orang-orang yang berpengaruh terhadap mereka.

3. Memberikan kontribusi data mengenai ide-ide, fakta, nilai, konsep yang tidak dimiliki masyarakat, tetapi bermanfaat bagi mereka dalam menghadapi realitas sosial dan masalah yang dihadapi mereka.

4. Membagi visi kepada masyarakat, harapan, dan aspirasi penyelenggara merupakan investasi bagi interaksi orang, masyarakat, dan kesejahteraan individu serta sosial.

5. Mendefinisikan syarat-syarat dan batasan-batasan situasi dengan sistem relasi antara pihak penyelenggara program dan masyarakat sasaran program yang dibentuk.

Aturan-aturan tersebut membentuk konteks bagi 'kontrak kerja' yang mengikat masyarakat dan lembaga. Batasan-batasan tersebut juga mampu menciptakan kondisi yang dapat membuat masyarakat dan pihak penyelenggara program pemberdayaan masyarakat menjalankan fungsinya masing-masing.

\section{METODOLOGI PENELITIAN}

Pendekatan metode yang digunakan adalah deskriptif kualitatif. Hal ini dikarenakan masalah penelitian berkaitan erat dengan sifat unik dari realitas sosial yang menyangkut pola pikir, cara pandang, sikap, dan perilaku manusia. Objek penelitian adalah lembaga (PKBM) dalam menerapkan strategi pemberdayaan terhadap warga belajar. Sumber data penelitian ini adalah peserta program keterampilan produktif berjumlah 40 orang dan pengelola PKBM berjumlah empat orang, sedangkan instansi terkait dan tokoh masyarakat dalam penelitian ini sebagai informan berjumlah tiga orang. Penelitian ini bertempat di PKBM Rawasari Kecamatan Cempaka Putih Jakarta Pusat pada bulan Agustus - September 2007.

\section{HASIL PENELITIAN}

Deskripsi Hasil Penelitian Berdasarkan Strategi Pemberdayaan yang dilakukan oleh PKBM Rawasari Strategi adalah cara untuk mengerahkan tenaga, dana, daya, dan peralatan yang dimiliki guna mencapai tujuan yang ditetapkan. Strategi dalam pemberdayaan masyarakat mempunyai beberapa tahapan sehingga kegiatan tersebut dapat terealisasi dengan baik. Tahapan-tahapan yang dimaksud adalah: (1) seleksi wilayah sasaran program, (2) sosialisasi pemberdayaan masyarakat, (3) pelaksanaan program pemberdayaan masyarakat, dan (4) monitoring dan evaluasi penyelenggaraan program pemberdayaan masyarakat.

Untuk setiap tahapan dapat dijelaskan sebagai berikut. 
1. Seleksi wilayah sasaran program

Seleksi wilayah dilakukan sesuai dengan kriteria yang disepati oleh lembaga, pihak-pihak terkait, dan masyarakat. Penetapan kriteria ini penting agar tujuan lembaga dalam pemberdayaan masyarakat akan tercapai serta pemilihan lokasi dilakukan sebaik mungkin. Dalam melakukan seleksi wilayah sasaran program, penyelenggara melakukan identifikasi wilayah sasaran program. Aspek-aspeknya meliputi hal-hal berikut.

a. Adanya masyarakat yang hidup dalam kondisi kekurangan (marjinal)

Peruntukan program-program pemberdayaan masyarakat perlu satu analisis yang mendalam dalam arti prioritas pendistribusiannya harus diperhatikan. Masyarakat marjinal atau masyarakat yang hidup dalam kondisi kekurangan dapat memiliki akses untuk menerima programprogram pemberdayaan dimaksud. Hasil dari penelitian menunjukkan bahwa para warga belajar yang mengikuti kegiatan di PKBM sebanyak 29 peserta atau $72,5 \%$ merupakan ibu rumah tangga yang dalam segi ekonomi telah mapan. Hal ini dapat dilihat dari hasil wawancara yang menyatakan bahwa para suami peserta program kebanyakan adalah pegawai negeri sipil dari Pemda serta pegawai swasta. Fakta ini mengindikasikan tidak selayaknya programprogram pemberdayaan diberikan terhadap masyarakat yang kurang membutuhkan. Artinya, program-program yang ada lebih tepat sasaran terhadap golongan masyarakat tertentu yang jelasjelas berada dalam kondisi kekurangan.

b. Dukungan dari aparat terkait dan tokoh masyarakat setempat

Dukungan dari aparat terkait seperti kelurahan dan kecamatan (pemerintah) merupakan hal yang sangat penting bagi penentuan lokasi program pemberdayaan. Dari total 40 responden, 36 responden atau $90 \%$ menyatakan mendapat dukungan dari aparat pemerintahan. Sementara itu, responden yang menyatakan tidak mendapatkan dukungan dari aparat pemerintahan sebanyak empat responden atau $10 \%$. Dapat disimpulkan bahwa pentingnya dukungan ini merupakan wujud kondisi yang dinamis, walau pemerintah hanya sebagai pengawas atau pemantau bagi keberlangsungan program-program pemberdayaan yang ada di masyarakat.

c. Daerah aman atau tidak rawan konflik

Penentuan wilayah program-program pemberdayaan mensyaratkan daerah yang aman atau tidak rawan konflik. Hal ini tercermin dari 35 responden atau $87,5 \%$ yang menyatakan wilayahnya aman atau tidak rawan konflik. Sementara responden yang lain tidak sependapat yang berarti wilayahnya tidak aman atau rawan dari konflik berjumlah lima responden atau 12,3\%. Dapat di indikasikan keamanan merupakan aspek paling penting bagi keberlangsungan pelaksanaan program-program pemberdayaan di masyarakat. d. Tidak ada kegiatan pemberdayaan lain

Aspek lain dalam penyeleksian wilayah pemberdayaan adalah tidak adanya program pemberdayaan lain. Penegasan frekuensi responden terhadap kenyataan tidak adanya program pemberdayaan lain sebanyak 30 responden atau $75 \%$. Sementara penegasan responden dengan kenyataan adanya program pemberdayaan lain sebanyak sepuluh responden atau $25 \%$. Dapat diindikasikan tidak adanya program pemberdayaan lain berarti minimnya program yang ada. Oleh karena itu, dengan adanya program tersebut masyarakat lebih merasakan manfaatnya dari berbagai segi aspek penentuan kelancaran program. Asumsi adanya program lain menjadikan tidak terkontrolnya progress terhadap program-program pemberdayaan yang berlangsung dan keberminatan terhadap program pemberdayaan cenderung kurang.

2. Sosialisasi program pemberdayaan masyarakat

Sosialisasi program pemberdayaan masyarakat adalah suatu kegiatan yang sangat penting untuk menciptakan komunikasi serta dialog dengan masyarakat. Sosialisasi program pemberdayaan pada masyarakat membantu untuk meningkatkan pengertian pada masyarakat dan pihak terkait tentang program. Proses sosialisasi sangat menentukan ketertarikan masyarakat untuk berperan dan terlibat di dalam program-program pemberdayaan masyarakat. Adapun mekanisme proses kegiatan sosialisasi yang dilakukan sebagai berikut.

a. Pertemuan formal dengan tokoh masyarakat dan aparat pemerintahan.

b. Kesepakatan terhadap wilayah sasaran program.

c. Pertemuan formal dengan masyarakat.

d. Pendekatan formal penyelenggara program melalui kegiatan seperti kunjungan ke rumah dan diskusi kelompok.

e. Peran atau partisipasi masyarakat dalam proses sosialisasi.

Dari hasil penelitian dapat dijelaskan bahwa 12 responden atau $30 \%$ menyatakan pertemuan formal 
dengan tokoh masyarakat dan aparat pemerintahan telah dilakukan sedangkan sisanya 28 responden atau $70 \%$ menyatakan pertemuan formal antara tokoh masyarakat dan aparat tidak dilakukan. Dari hasil tersebut dapat dikatakan bahwa dalam tahap sosialisasi, pihak pengelola kurang memberikan kesempatan kepada masyarakat untuk memperoleh berbagai informasi tentang program pemberdayaan itu sendiri, padahal dalam pertemuan formal ini masyarakat diberi kesempatan untuk menemukan sendiri permasalahan dan prioritas kebutuhan melalui proses musyawarah atau kesepakatan yang menjadi pilihannya. Selain itu, dalam pertemuan tersebut dapat digali juga informasi-informasi yang ada di masyarakat.

Peran atau partisipasi masyarakat dalam proses sosialisasi terepresentasi oleh mayoritas responden dengan perolehan 33 responden atau 82,5\%. Hal ini menunjukkan peran atau partisipasi masyarakat sangat antusias untuk terselenggaranya programprogram pemberdayaan karena dengan adanya dukungan dari masyarakat sangat memungkinkan terus bergulirnya program-program pemberdayaan. Terlebih lagi jika ada pendekatan informal penyelenggara program melalui kegiatan, seperti kunjungan ke rumah dan diskusi kelompok akan sangat memperlancar bergulirnya program di masyarakat namun hal tersebut belum dilakukan oleh pihak penyelenggara. Berdasarkan hasil wawancara dengan pihak penyelenggara, dikatakan bahwa proses sosialisasi dilakukan dengan mencari informasi dari ibu-ibu Pemberdayaan dan Kesejahteraan Keluarga (PKK) sehingga hanya masyarakat tertentu yang mendapatkan informasi adanya program-program pemberdayaan.

Selain melakukan mekanisme proses sosialisasi yang dipaparkan di atas aspek-aspek yang penting dalam melakukan proses sosialisasi antara lain sebagai berikut.

a. Mengenal penyelenggara program pemberdayaan di PKBM Rawasasari berdasarkan hasil penelitian, diketahui bahwa hampir sebagian responden tidak mengenal penyelenggara program, hal ini dapat dilihat dari 40 responden hanya 13 responden atau $32,5 \%$ yang mengenal penyelenggara program, sementara sebanyak 27 responden atau $67,5 \%$ tidak mengenal penyelenggara program. Sangat dominannya responden yang tidak mengenal pihak penyelenggara program menunjukkan sosialisasi yang kurang dari pihak penyelenggara dan belum terbentuknya hubungan yang harmonis antara pihak penyelenggara program dengan warga belajar.

b. Penyelenggara program senantiasa bergaul dengan masyarakat. Berdasarkan hasil penelitian yang telah dilakukan ternyata mayoritas responden, yaitu 39 responden atau 97,5\% menjawab tidak. Hal ini semakin menunjukkan pergaulan yang kurang dari pihak penyelenggara dengan masyarakat sasaran program.

3. Pelaksanaan program pemberdayaan masyarakat PKBM adalah lembaga yang berorientasi pada pendidikan masyarakat dalam arti sebagai wadah berbagai kegiatan belajar masyarakat untuk meningkatkan pengetahuan, keterampilan, dan sikap yang diperlukan untuk mengembangkan diri dan masyarakat. Sasaran dari peserta program di PKBM adalah masyarakat umum yang membutuhkan layanan pendidikan yang tersedia di PKBM dan yang tidak dapat bersekolah di sekolah formal. Oleh karena itu, dalam proses kegiatannya sangat berbeda dengan pendidikan formal, yaitu kegiatan yang pelaksanaannya berbasis pemberdayaan masyarakat. Berdasarkan hal tersebut, berikut hasil penelitian dari beberapa aspek yang digunakan dalam pelaksanaan programprogram di PKBM.

a. Penyelenggara program menjelaskan tujuan dasar program

Berdasarkan hasil penelitian yang telah dilakukan, mayoritas responden sebanyak 35 responden atau 87,5\% menyatakan penyelenggara program menjelaskan tujuan dasar program, sementara hanya lima responden atau 12,5\% yang menyatakan tidak. Dengan kondisi tersebut mengindikasikan kelancaran dari program yang digulirkan karena dengan adanya penjelasan dari pihak penyelenggara program masyarakat sasaran mengetahui manfaat dari program-program tersebut. Dari hasil wawancara juga diungkapkan bahwa para peserta program pemberdayaan akan senantiasa mengikuti program-program yang ada di PKBM.

b. Kesesuaian program dengan kebutuhan masyarakat

Walaupun dalam proses sosialisasi pihak penyelenggara program dikatakan kurang maksimal namun ternyata mayoritas responden, sebanyak 33 responden atau 82,5\%, menyatakan bahwa program-program yang digulirkan telah sesuai dengan kebutuhan sedangkan responden yang menyatakan ketidaksesuaian program dengan kebutuhan dirinya hanya tujuh responden atau 
$17,5 \%$. Hal ini dapat disimpulkan bahwa berjalan maksimal atau tidaknya proses sosialisasi yang dilakukan, masyarakat telah dapat menilai seperti apakah program yang sesuai dengan kebutuhan dirinya.

\section{c. Adanya pembentukan kelompok}

Kelancaran suatu program pemberdayaan yang ada di masyarakat sasaran sangat ditentukan oleh ada tidaknya kelompok dalam kegiatan tersebut karena keberadaan suatu kelompok membuat ikatan-ikatan, baik secara fisik maupun emosional. Di samping itu, dengan dibentuknya kelompok-kelompok dalam peserta program pemberdayaan akan sangat mampu meningkatkan efektivitas pelaksanaan koordinasi dan sinkronisasi hal-hal yang penting terkait dengan pelaksanaan program pemberdayaan. Dengan adanya kelompok juga memungkinkan anggota kelompok bekerja sama dengan anggota yang lain baik formal maupun informal untuk berbagi pengetahuan dan pengalaman guna mencapai tujuan bersama. Pembentukan kelompok juga diperlukan dalam rangka meningkatkan kemandirian. Dari hasil penelitian hal ini telah dilakukan terbukti dari 30 responden atau 75\% yang menyatakan adanya pembentukan kelompok, sementara sepuluh responden atau 25\% menyatakan tidak dibentuk kelompok.

d. Waktu kegiatan disesuaikan dengan peserta program pemberdayaan

Dari hasil penelitian yang dilakukan, ditemukan 30 responden atau $75 \%$ menyatakan ada kesepakatan waktu pelaksanaan program pemberdayaan antara pihak penyelenggara dengan peserta program pemberdayaan. Adapun responden yang menyatakan tidak adanya kesepakatan waktu pelaksanaan program pemberdayaan antara penyelenggara dengan peserta berjumlah sepuluh responden atau $25 \%$. Dapat disimpulkan bahwa adanya keterlibatan yang aktif dari peserta program pemberdayaan masyarakat. Hal ini juga mengindikasikan adanya proses pembelajaran kepada masyarakat agar mereka dapat menemukan cara-cara pemecahan permasalahan dan kebutuhan dari diri mereka sendiri sehingga kemungkinan berhentinya program pemberdayaan yang ada sangat kecil.

4. Monitoring dan evaluasi penyelenggaraan program pemberdayaan masyarakat

Indikator keberhasilan suatu program pemberdayaan adalah meningkatnya kualitas hidup dari peserta program pemberdayaan. Untuk mengetahui tingkat keberhasilan suatu program pemberdayaan maka perlu adanya evaluasi yang dilakukan oleh penyelenggara program pemberdayaan. Kegiatan evaluasi adalah kegiatan yang sangat penting dalam pelaksanaan program pemberdayaan masyarakat. Dengan adanya evaluasi maka akan diketahui sejauhmana efektivitas dan efisiensi program pemberdayaan masyarakat dilakukan. Secara umum dikenal dua tipe evaluasi, yaitu on going evaluation atau evaluasi terus menerus dan ex post evaluation atau evaluasi akhir. Evaluasi berusaha mengidentifikasi mengenai apa yang sebenarnya terjadi pada pelaksanaan atau penerapan program. Evaluasi bertujuan untuk:

a. mengidentifikasi tingkat pencapaian tujuan,

b. mengukur dampak langsung yang terjadi pada kelompok sasaran, dan

c. mengetahui dan menganalisis konsekuensikonsekuensi lain yang mungkin terjadi di luar rencana.

Aspek-aspek yang dimonitor dan dievaluasi meliputi proses, pencapaian, dan dampak proses pemberdayaan. Dari hasil penelitian menunjukkan pihak penyelenggara pemberdayaan masyarakat senantiasa melakukan monitoring dan evaluasi. Hal ini dinyatakan oleh mayoritas responden sebanyak 37 responden atau $92,5 \%$. Responden yang menyatakan tidak, hanya tiga orang atau 7,5\%. Evaluasi yang dilakukan berdasarkan hasil wawancara dan pengamatan adalah baru sebatas evaluasi terhadap hasil pembelajaran, yakni dalam bentuk penilaian hasil kegiatan yang dilakukan oleh peserta program pemberdayaan. Misalnya, untuk kursus menjahit yang dinilai adalah apakah peserta telah mampu menghasilkan suatu produk. Demikian pula halnya dengan kursus memasak dan kursus hantaran, evaluasi dilakukan hanya sebatas pada hasil kegiatan yang kemudian apabila peserta program pemberdayaan yang memiliki hasil penilaian terbaik dapat mengikuti lomba-lomba yang diadakan oleh instansi terkait seperti lomba antar PKBM yang selalu diadakan setiap bulan Juni dan September. Kegiatan evaluasi seharusnya meliputi seluruh proses tahapan dalam penyelenggaraan kegiatan pemberdayaan masyarakat serta dampak atau pengaruh dari pelaksanaan program pemberdayaan.

Bicara tentang pengaruh dari adanya program pemberdayaan di masyarakat, ternyata dari total 40 responden, yaitu sebanyak 22 responden atau 55\%, menyatakan adanya pengaruh yang diperoleh setelah mengikuti program pemberdayaan masyarakat di PKBM. Pengaruh yang dimaksud adalah mereka memperoleh keterampilan yang dapat digunakan untuk menambah penghasilan keluarga, seperti kursus 
hantaran, yaitu keterampilan menghias barang bawaan untuk mempelai. Dari hasil wawancara, dapat disimpulkan bahwa peserta program pemberdayaan sangat merasakan sekali manfaat yang diperolehnya karena jenis keterampilan tersebut tidak banyak memerlukan dana yang besar. Keterampilan ini hanya membutuhkan kreativitas dan kemauan yang besar dari peserta program pemberdayaan, di samping tentunya penyaluran dari pihak penyelenggara program pemberdayaan kepada pengguna jasa.

Adanya penyaluran dari penyelenggara program kepada pihak pengguna jasa dinyatakan oleh sebanyak 14 responden atau 35\%. Responden yang menyatakan tidak adanya penyaluran dari pihak penyelenggara program pemberdayaan kepada pengguna jasa sebanyak 26 orang atau $65 \%$. Dari hasil penelitian tersebut dapat dikatakan bahwa dalam melakukan program pemberdayaan, pihak penyelenggara belum sepenuhnya melaksanakan pemberdayaan secara holistik yang memadukan antara kegiatan-kegiatan dengan kebijakan sosial secara terintegrasi. Pemberdayaan masyarakat yang demikian bukan saja kurang efektif, melainkan tidak berkelanjutan. Diibaratkan dengan analogi “ikan dan kail", meskipun kelompok sasaran (target grup) diberi ikan dan kail sekaligus, mereka tidak akan berdaya jika seandainya kolam dan sungai yang ada diseputar mereka telah dikuasai oleh kelompok lain. Jika demikian, tujuan program pemberdayaan masyarakat, yaitu kemandirian peserta program pemberdayaan, belum sepenuhnya terwujud.

5. Pengaruh pelaksanaan program terhadap perubahan ekonomi masyarakat

Dilihat dari kondisi ekonomi masyarakat terutama peserta program pemberdayaan di PKBM Rawasari secara umum, tampaknya tidak ada perubahan secara signifikan terhadap peningkatan kondisi ekonomi. Adapun pada tujuan dasar program keterampilan produktif lebih mengarah pada peningkatan ekonomi keluarga. Berdasarkan hasil penelitian, yang dilakukan dari 40 responden, hanya sekitar $20 \%$ yang menyatakan ada perubahan pada kondisi ekonomi mereka. Menurut mereka tidak adanya penyaluran kepada pengguna jasa diduga merupakan salah satu penyebabnya. Padahal dengan menumbuhkembangkan kemitraan atau kerja sama antara PKBM dengan dunia usaha merupakan salah satu implementasi dari visi dan misi PKBM.

\section{KESIMPULAN}

Kesimpulan yang dapat diperoleh dari hasil penelitian ini adalah bahwa dalam melaksanakan program pemberdayaan, pihak penyelenggara dalam hal ini PKBM Rawasari belum sepenuhnya melakukan pemberdayaan secara holistik. Walaupun demikian, kebermanfaatan dari program pemberdayaan yang ada sangat dirasakan oleh peserta program pemberdayaan. Namun, dalam strategi yang dilaksanakan belum sepenuhnya mengacu pada konsep-konsep pemberdayaan. Seperti dalam tahap sosialisasi yang dianggap kurang maksimal sehingga program pemberdayaan yang ada kurang mengena pada sasaran yang lebih membutuhkan. Pengaruh dari kurangnya sosialisasi kepada masyarakat, hubungan antara pihak penyelenggara dengan peserta program pemberdayaanpun kurang harmonis. Begitu pula halnya dengan proses penentuan program pemberdayaan yang kurang melibatkan masyarakat. Program-program yang ada dibatasi oleh ketersediaan dana yang ada. Di samping itu, tidak ada penyaluran dari pihak penyelenggara program kepada pengguna jasa.

Beberapa rekomendasi yang dapat disampaikan kepada para pengambil kebijakan terhadap permasalahan yang ada di lapangan dan untuk mengoptimalkan program pemberdayaan masyarakat adalah sebagai berikut.

1. Dalam melaksanakan program pemberdayaan masyarakat, sebaiknya peserta program merupakan masyarakat yang memang benar-benar membutuhkan. Masyarakat dilibatkan dalam proses perumusan program. Hal ini dikarenakan program yang didasari atas kebutuhan masyarakat akan lebih mempengaruhi masyarakat untuk bertanggung jawab terhadap program dan keberhasilannya.

2. Hendaknya dilakukan proses sosialisasi secara masif sebelum pelaksanaan program pemberdayaan.

\section{DAFTAR PUSTAKA}

Hikmat, H. (2001). Strategi pemberdayaan masyarakat. Bandung: Humaniora Utama Press.

Miles, M.B.A. \& Huberman, M. (1992). Analisa data kualitatif, buku tentang metode-metode baru. Jakarta: UI Press.

Moleong, L.J. (1996). Metodologi penelitian kualitatif. Bandung: Remaja Rosdakarya.

Sihombing, U. (2000). Pendidikan luar sekolah. Manajemen strategi, konsep, kiat, dan pelaksana. Jakarta: PD Mahkota. 
Suharto, E. (2006). Pembangunan kesejahteraan sosial dalam pusaran desentralisasi dan good governance. Makalah disampaikan pada Semiloka Kompetensi Sumber Daya Manusia Kesejahteraan Sosial di Era Desentralisasi dan Good Governance. Balai Besar Pendidikan dan Pelatihan Kesejahteraan Sosial (BBPPKS), 21 Maret 2006, Banjarmasin.

Sumaryo. (1991). Implementasi Participatory Rural Appraisal (PRA) dalam pemberdayaan masyarakat. Disampaikan dalam pelatihan pengorganisasian masyarakat dalam rangka peningkatan mutu pengabdian pada masyarakat, di IAIN Raden Intan Bandar Lampung, 26 November 2005.

\section{KETERANGAN PENULIS}

Puji Hardiyanti, M.Sc dilahirkan di Jakarta, Oktober 1974. Saat ini aktif sebagai dosen PLS FIP UNJ. Artikel terbaru yang pernah ditulis adalah Esensi Penyuluhan dalam Pendidikan Luar Sekolah dan Perspektif Vol 15 Tahun 2007 dengan judul Pembangunan Masyarakat dalam Perspektif Penyuluhan. 